\title{
The False Promise of Worker Capitalism: Congress and the Leveraged Employee Stock Ownership Plan
}

\author{
William R. Levin
}

Employee stock ownership plans (ESOPs) are a form of statutory pension program designed to invest employee retirement assets in the stock of the employer. ${ }^{1}$ A leveraged ESOP borrows money to finance the stock purchase. As a congressionally sanctioned "technique of corporate finance,"2 the leveraged ESOP program represents the leading legislative effort to date to transfer controlling equity blocks in American corporations from outside shareholders to workers. While the cost of the program's tax subsidies has not been reliably calculated, the foregone revenues to the Treasury could well exceed several billion dollars annually. ${ }^{3}$

1. For a description of the ESOP program and governing statutes, see infra note 11. See also infra notes $12-15,23,29$ and accompanying text.

2. 129 Cong. REC. S16629, S16636 (daily ed. Nov. 17, 1983) (statement of Sen. Long) [hereinafter cited as Long Statement]. See also J. KAPLAN \& R. Ludwig, ESOPs A-16 (BNA Tax Mgmt. Portfolio No. 354-2nd, 1983) ("[Leveraged ESOPs] can be used for financing corporate growth, tender offers, acquisitions, going private, or increasing the corporation's working capital. Leveraged ESOPs are thought to be especially useful in mergers or divestitures of subsidiaries and shareholder buy-outs.").

3. According to the Office of Management and Budget, the total cost of ESOP subsidies will amount to $\$ 2.5$ billion in 1986 , increasing to at least $\$ 4.4$ billion by 1990 . Hoerr, ESOPs: Revolution or Ripoff?, Bus. Wr., Apr. 15, 1985, at 94, 94.

Two analytic problems make more precise estimation difficult. First, foregone tax dollars are properly measured relative to an alternative corporate structure, but such a comparison is difficult to establish without the equivalent of a tax expenditure budget. See Bittker, Accounting for Federal "Tax Subsidies" in the National Budget, 22 NAT'L TAX J. 244, 248 (1969) (measurement of subsidies requires construction of "ideal or correct income tax structure, departures from which will be reflected as 'tax expenditures' in the National Budget"). For a definition of tax expenditure and a discussion of associated difficulties of measurement, see Graetz \& McDowell, Tax Reform 1985: The Quest for a Fairer, More Efficient and Simpler Income Tax, 3 YALE L. \& POL'Y REV. 5, 13 (1984) ("Tax expenditures are defined generally as provisions of the Internal Revenue Code that allow special exclusions, deductions, deferrals or credits to encourage particular economic activities or to benefit particular categories of taxpayers.").

Assume, for example, a public corporation paying $\$ 100$ in tax chooses an employee buyout (resulting in no taxable income due to tax expenditures) over a conventional, non-employee buyout (paying $\$ 50$ in taxes). No good theory exists for determining whether the ESOP tax expenditure is incremental to the tax bill of the initial corporation or to the tax bill resulting from the rejected conventional deal.

Second, cost estimates will depend on the number and size of deals closed in the future. Lawyers and bankers generally report an extremely high interest in leveraged ESOPs, and the size of deals is exploding. See, e.g., National Center For Employee Ownership, New Tax Law Causes Surge in Interest in Employee Ownership, EMPLOYEE OwNERSHIP, Feb. 1985, at 5 (available from the National Center For Employee Ownership, Arlington, Va.). The flexibility of the leveraged ESOP as a 


\section{Leveraged ESOPs}

And unlike the vast array of consumption-oriented transfer programs sponsored by the government, the leveraged ESOP program aims to shift ownership of the nation's productive assets to workers. ${ }^{4}$

The program's impact extends from the small, closely-held corporation to the largest enterprises in the United States. ${ }^{5}$ At the political level, numerous groups view leveraged ESOPs as a key tool for social reform and national industrial policy. ${ }^{6}$ Many state governments have adopted similar

financing vehicle may result in a program far more costly than anticipated.

4. The ESOP program's goal is to broaden capital ownership. See infra text accompanying notes 43-51. The "institutions and conventions of finance" are specifically intended to be the instrumentalities that will distribute ownership of capital "that has yet to be created." Long Statement, supra note 2, at S16634.

5. Numerous factors motivate the use of leveraged ESOPs. Some managers of public companies prefer a private, closely-held operating structure. See, e.g., The Tax Magic That's Making Employee Stock Plans Multiply, Bus. WK., Oct. 15, 1984, at 158, 158 (William Leonhard, President of Parsons Corporation, "long wanted to restructure his company along the lines of a law or accounting firm, in which employees can be rewarded-and motivated-as if they were partners."). In closely-held firms, aging owners may want liquidity or the current owners may decide that the workers are the group best equipped to continue running the firm. See National Center for Employee Ownership, Companies, EMPLOYEe OWNERSHIP, Feb. 1985, at 2 [hereinafter cited as Companies]. Public companies have responded to hostile takeover bids by going private or placing a large block of stock in an employee trust. In the latter case, the presumption is that workers are less likely than mutual fund portfolio managers to sell out management. See, e.g., Comment, Employee Stock Ownership Plans and Corporate Takeovers: Restraints on the Use of ESOPs by Corporate Officers and Directors to Avert Hostile Taheovers, 10 Pepperdine L. Rev. 731, 733 (1983); Rosen and Caudell-Feagan, Using ESOP's to Thwart Hastile Takeovers-Beware!, Pension WorLd, Feb. 1984, at 18, 18-20.

Public companies also sell off divisions or subsidiaries which fail to meet corporate targets for growth and profitability. Employees are typically most interested in these so-called distress buyouts when the operations provide substantial employment in the local community. The $\$ 368$ million buyout of the aging Weirton Steel plant from National Steel is the leading example. See, e.g., Kuttner, Blue-Collar Boardrooms, NEw REPUBLIC, June 17, 1985, at 18, 21-22. Other ESOP uses include the refinancing of existing pension plans or general corporate refinancing. See, e.g., Companies, supra note 5, at 2. See generally Sherman \& Lewis, The ESOP Fallacy, 3 J. Pension PLAN. \& CoMpLIANCE 226, 234-44 (1977) (skeptical analysis of thirteen transactions said to be well-suited to ESOP financing). A novel, and as yet untried, use of the leveraged ESOP is as the vehicle supporting a hostile takeover raid.

6. Employee ownership has been promoted, inter alia, as (1) the means to "restructure the shop floor and guide the flow of capital, technology, and human resources into more creative systems of self-management;" (2) "early evidence of a coming Second Industrial Revolution . . . characterised by participation and ownership of the means of production;" (3) the vehicle for fulfillment of "responsible social justice in America." Woodworth, Towards a Labour-Owned Economy in the United States, 6 LAB. \& Soc'y 41, 43 (1981); and (4) as an "attractive and practical 'third way' between market capitalism and state socialism." C. Rosen \& W. Whyte, Encouraging Employee Ownership: The Government's Role (Nov. 1983), reprinted in NATIONAl GeNTER FOR EMPLOYEe OWNERShIP, A LeGISLATIVE GUide to EMPLOYeE OWNERSHIp 46 (1984).

More immediate ends to be achieved by employee ownership range from increased worker control, see, e.g., Krimerman, Gathering Strength: Worker Ownership and Control in the 80's, CHangING WORK, Fall 1984, at 20, 25 (1984); to resurgent trade unionism, Kuttner, supra note 5, at 23; job preservation, Olson, Union Experiences With Worker Ownership: Legal and Practical lssues Raised by ESOPS, TRASOPS, Stock Purchases and Cooperatives, 1982 Wrs. L. REv 729, 742-760; and even a "centerpiece" role in defeating hostile takeover bids, Blumstein, New Role for Employee Plans, N.Y. Times, Jan. 2, 1985, at D1, col. 3. In such an environment, the observation that ESOPs, whether leveraged or unleveraged, represent an allocation of compensation between current and deferred accounts is easily forgotten. See infra note 30. 
employee ownership programs and subsidies as an integral part of local economic development initiatives.

This Note analyzes leveraged employee buyouts as a core application of the leveraged ESOP program. ${ }^{8}$ These buyouts highlight the contention of Congress that leveraged employee ownership can boost productivity, transfer wealth without expropriation or tax redistribution, and transform workers into capitalists.

This Note argues that both the premise and the structure of leveraged

7. Twelve states have passed laws endorsing the concept of employee ownership and/or providing direct aid for technical and financial assistance: California, Connecticut, Delaware, Illinois, Maryland, Michigan, New Hampshire, New Jersey, New York, Pennsylvania, West Virginia and Wisconsin. See generally National Center For EMPLOYEe Ownership, supra note 6, at II-1 to II-10 (describing legislation in 10 states); National Center for Employec Ownership, Wisconsin Legislation Encourages Employee Ownership, EMPLOYEe OWNERSHIP, Apr. 1985, at 5; National Center for Employee Ownership, Connecticut Sets up Employee Ownership Fund, EMPLOYEe OwNERSHIP, June 1985 , at 8. Under the Pennsylvania program, loans and loan guarantees will be provided to support employee buyouts for firms "facing a threat of substantial layoffs or a plant closing." EmployceOwnership-Assistance Program, PA. Stat. AnN. tit. 73, § 396.5(a)-(b) (Purdon Supp. 1985). This provision reflects the belief that "employee ownership . . . can successfully prevent a plant shutdown." Department of Commerce, Commonwealth of Pennsylvania, Pennsyluania EcoNOMic Revitalization Fund 1 (Nov. 1984). In addition, the program provides loans for technical assistance "to develop or improve an employee-owned enterprise." PA. STAT. ANN. tit. 73, § 396.4(a) (Purdon Supp. 1985). This provision reflects the belief that "employee ownership can lead to increased productivity and profitability." Department of Commerce, Commonweath of PennsyLvANIA, supra, at 1 .

8. A leveraged buyout refers to a financing transaction in which a buyer borrows funds secured by the assets and earning power of the acquisition target in order to purchase control of the corporation from selling shareholders. When the leveraged ESOP structure is used as part of the financing package, the transaction is known as a leveraged employee buyout.

To avoid confusion, two types of employee buyouts need to be distinguished. In the buyout of healthy companies, management and investors direct the proportion of stock to be owned by workers in the ESOP trust. As fiduciaries of the trust, management executives will generally control voting rights of the ESOP stock for at least as long as the buyout debt is outstanding. See infra note 76. Only in buyouts of distressed companies will workers end up with all the stock, principally because in these cases other investors have little interest in buying the firm. See Kuttner, supra note 5, at 22; M. Kieschnich, J. Parzen, C. Rosen, \& C. Squire, Employee Buyout Handbook 5-8a (1985) (description of employee buyouts as an alternative to plant closing). Despite the sharp divergence of form, both transactions are generally referred to as employee buyouts.

The first administratively sanctioned use of debt as applied to an employee pension plan was the leveraging of a defined contribution plan allowed in a 1953 IRS revenue ruling. Granados, Employee Stock Ownership Plans: An Analysis of Current Reform Proposals, 14 J. L. ReForm 15, 18-19 (1980) (citing Rev. Rul. 46, 1953-1 C.B. 287). The first application of the leveraged ESOP buyout occurred in 1956 when a small newspaper averted a takeover by a major chain. Id.

Recent major leveraged employee buyouts include Blue Bell, the manufacturer of Wrangler jeans (sale price of $\$ 470$ million), Wall St. J., July 25, 1984, at 5, col. 1; Parsons Corporation, an engineering firm ( $\$ 557$ million), Wall St. J., Sept. 28, 1984, at 12, col. 4; Weirton Steel ( $\$ 386$ million), Wall St. J., Sept. 26, 1983, at 16, col. 3; Raymond International (\$165 million), Wall St. J., Nov. 10, 1983, at 22 , col. 1; and Dan River (\$154 million), Wall St. J., May 25, 1983, at 10, col. 2.

The stirring rhetoric and tangible tax benefits from Congress presage a continuing rise in popularity for the employee buyout. In the words of a union official at a major airline, "'there probably isn't an employee intensive corporation in America that isn't thinking about [a leveraged worker buyout]." Wall St. J., Feb. 21, 1985, at 24, col. 2. T. Boone Pickens, Chairman of Mesa Petroleum, stated to the press that the leveraged employee buyout has the potential to "financially restructure America." Wall St. J., Nov. 27, 1984, at 20, col. 2.

9. See infra text accompanying notes 43-52. 
ESOPs are fatally defective. After placing the program in the setting of tax and pension law, the Note in Part I identifies the principal arguments supporting leveraged ESOPs. Part II analyzes these arguments using modern financial theory and finds them wanting. Part III offers evidence that the program systematically injures workers and the economy as a whole. The Note concludes by suggesting that the program is costly, harmful, and unnecessary, and should be abolished. Instead, Congress should rely on individual firms to decide without the bias of tax subsidies whether to invest worker assets in employer securities.

\section{The Congressional Program}

\section{A. The Statutory Setting}

A brief guide to pension law as applied to a leveraged ESOP transaction sets the context for analyzing the congressional program and the associated tax subsidies. ${ }^{10}$ The term "ESOP" refers generically to a statutory pension program that invests primarily in employer stock. ${ }^{11}$ As one of sev-

10. There is a modest literature explaining the ESOP concept and assessing its significance as an employee benefit. For discussion of statutes and implementing regulations, see KaPLAN \& LuDwIG, supra note 2 (analysis of ESOPs and leveraged ESOPs); Subcommittee on Employee Stock Ownership Plans, Committee on Employee Benefits, Section of Taxation, American Bar Association, ESOPs Foibles, 31 TAx LAw. 561, 561-613 (1978) (general discussion of ESOP program); Menke, ESOP's New Look Under the Final Regulations, 5 J. Pension Plan. \& Complance 213, 213-38 (1979) (description of IRS regulation of ESOPs); Ludwig \& Curtis, ESOPs Made Substantially More Attractive as a Result of Economic Recovery Tax Act 55 J. TAX'N 208, 208-11 (1981) (explanation of increased ESOP benefits under the Economic Recovery Tax Act of 1981).

For generally favorable evaluations of ESOPs and their potential, see Altmann, The ESOP Revisited: A Reinterpretation of Employee Stock Ownership Plans, 5 J. Pension Plan \& Compliance 160, 160-67 (1979) (ESOPs can increase returns on invested capital and are superior to profitsharing); Granados, supra note 8 (historical background and analysis of proposed legislative reforms); Olson, supra note 6 (broad review of organized labor use of employee ownership structures, including ESOPs).

For articles skeptical of ESOP benefits, both financial and economic, see Kaplan, ESOP's Fable, 53 TAXES 898, 898-912 (1975) (equivalent or superior results achievable through non-ESOP planning techniques); Carlson, ESOP and Universal Capitalism, 31 TAx L. REv. 289, 299-300, 312-15 (1976) (ESOP forces loss of diversification and amounts to program of redistribution, not wealth creation); Sherman \& Lewis, supra note 5 (skeptical analysis of ESOP applications).

11. See Employee Retirement Income Security Act of 1974 (ERISA), Pub. L. No. 93-406, 88 Stat. 829 (codified as amended at 29 U.S.C. $\S \S 1001-1461$ (1982 \& Supp. I 1983) and parallel governing provisions under the Internal Revenue Code of 1954, as amended, at I.R.C. $\S \S 401-409$ and other scattered provisions (West Supp. 1985)).

Under ERISA, an ESOP is defined as a tax-qualified stock bonus plan that is designed to invest primarily in "qualifying employee [sic] securities" and that meets "such other requirements as the Secretary of the Treasury may prescribe by regulation." ERISA § 407(d)(6), 29 U.S.C. § 1107(d)(6) (1982). Under the Internal Revenue Code, an ESOP is strictly defined as an employee stock bonus plan, or a combination of a stock bonus and money purchase plan, which meets special regulatory and statutory provisions relating to its operation and holding of stock. I.R.C. $\S 4975$ (e) (7)-(8) (West Supp. 1985); Treas. Reg. $\S 54.4975-11$, T.D. 7571, 1979-1 G.B. 368, 368-70.

As a defined contribution plan, the ESOP credits contributions to individual employee accounts such that future benefits depend upon the return earned by the employer stock and other invested securities. I.R.C. $\S 411$ (i) (1982). In the alternative form of pension plan authorized under the Code, the defined benefit plan, retirement benefits are defined in advance rather than tied to actual perform- 
eral "eligible individual account plans,"12 the ESOP is exempt from the general requirements of the Employee Retirement Income Security Act of 1974 (ERISA) that pension plans be diversified, ${ }^{13}$ and that no more than 10 percent of the plan's assets be invested in employer stock. ${ }^{14}$ In addition, the ESOP is exempt from the general prohibition against transactions between a pension plan and the sponsoring corporation. ${ }^{15}$

In the simplest case, an employer will establish an ESOP trust and thereafter make annual contributions to the trust in the form of employer stock. The corporation can deduct the contribution, but the value of the stock is not included in the income of the employee until withdrawal. ${ }^{16}$ The tax-free accumulation of investment income in the pension fund rep-

ance. I.R.C. $\S 411(j)(1982)$.

The first statutory discussion of employee ownership appeared in the Regional Rail Reorganization Act of 1973, Pub. L. No. 93-236, $\S 102(5), 301($ e), 87 Stat. 985, 987, 1005 (1974) (prior to 1976 amendment). The principal legislation subsequent to ERISA appears in the Trade Act of 1974, Pub. L. No. 93-618, § 273(f), 88 Stat. 1978, 2038-39 (1975) (codified at 19 U.S.C. $\S 2373(f)(1982)$ ) (preferential loan guarantees to ESOP firms injured by foreign competition); Tax Reduction Act of 1975, Pub. L. No. 94-12, § 301, 89 Stat. 26, 36-40 (tax-credit ESOP) (repealed 1984); Revenue Act of 1978, Pub. L. No. 95-600, $\$ 1141-43,92$ Stat. 2763, 2787-96 (codified as amended at 26 U.S.C.A. $\S 409$ (West Supp. 1985) and in other scattered sections of 26 U.S.C.) (adding technical qualifications for ESOPs); Small Business Employee Ownership Act of 1980, Pub. L. No. 96-302, §§ 501-07, 94 Stat. 833, 850-54 (1980) (codified as amended at 15 U.S.G. $\$ \S 632(c), 636(a)(15)$ (1982)) (SBA loan guarantees for purchase of employer stock by ESOP trust resuiting in majority ownership by trust); Economic Recovery Tax Act of 1981 (ERTA), Pub. L. No. 97-34, \$§ 331-339, 95 Stat. 172, 289-298 (codified as amended at 26 U.S.C.A. $\$ \S 41,404(a)(9)$ (West Supp. 1985) and in other scattered sections of 26 U.S.C.) (creating ESOP credit and raising deductible limit on employer pension contributions from $15 \%$ to $25 \%$ of payroll costs); and the Deficit Reduction Act of 1984, Pub. L. No. 98-369, $\S \S 541-545,98$ Stat. 494, 887-96 (codified at 26 U.S.C.A. $\S \S 1042,404(\mathrm{k}), 133,2210,4978$ (West Supp. 1985)) (tax-free rollover, dividend deduction, interest exclusion, assumption of estate tax liability, and excise tax on certain dispositions).

For a legislative history of the ESOP program, see Granados, supra note 8, at 18-20. For a discussion of other ERTA provisions affecting ESOPs, see Ludwig \& Curtis, supra note 10. For a discussion of provisions of the Deficit Reduction Act of 1984 that affect ESOPs, see Vogel \& Rosen, Myriad of New Tax Incentives Allowed for ESOPs, Legal Times, July 23, 1984, at 12, col. 1.

12. ERISA $\S 407($ d)(3), 29 U.S.C. § 1107(d)(3) (1982) (defining "eligible individual account plan," which includes profit-sharing, stock bonus, thrift, savings, ESOP, or money purchase pension plans).

13. ERISA § 404(a)(2), 29 U.S.C. $§ 1104(a)$ (2) (1982) (exempting an individual eligible account plan from diversification requirement for purposes of acquiring and holding qualifying employer real property or securities). Under ERISA, fiduciaries are required to diversify plan investments to minimize the risk of large losses, unless clearly imprudent. ERISA $\S 404(a)(1)(C), 29$ U.S.C. $\$ 1104(a)(1)(C)$ (1982).

14. ERISA \$ 407(b)(1), 29 U.S.C. § 1107(b)(1) (1982). Under ERISA, a pension plan may not invest more than $10 \%$ of the fair market value of its assets in qualifying employer securities and real property. ERISA $\S 407(a)(2), 29$ U.S.C. $\S 1107(a)(2)(1982)$.

15. ERISA $\S 408(e)(3)(A), 29$ U.S.C. $\S 1108(e)(3)(A)(1982)$ and I.R.C. $\S 4975$ (d)(13) (1982) (acquisition, sale, or lease exemption); ERISA $\S 408(b)(3), 29$ U.S.C. $\S 1108(b)(3)$ (1982) (leveraged ESOP loan exemption). Ordinarily, transactions between a plan and "a party in interest" (i.e., the sponsoring corporation) are prohibited, ERISA § 406, 29 U.S.C. 1106 (1982), subject to certain exemptions, ERISA § 408, 29 U.S.C. § 1108 (1982).

16. See A. Munnell, The Economics of Private Pensions 35-36 (1982). 
resents a subsidy authorized by Congress for all pension saving plans, ESOP and non-ESOP alike. ${ }^{17}$

Beyond this general subsidy to pension plans, ESOPs benefit from various additional tax subsidies, including a corporate deduction for dividends paid on ESOP stock ${ }^{18}$ and the assumption of estate tax liability by the ESOP. ${ }^{10}$ Non-tax benefits include eligibility for Small Business Administration loan guarantees, ${ }^{20}$ preference for government loans to ESOP firms injured by foreign competition, ${ }^{21}$ and increased allowable pension allocations to individual accounts. ${ }^{22}$

Finally, in addition to these benefits conferred on pension plans and ESOPs in general, the leveraged ESOP has the statutory right to finance the trust stock purchase with debt. ${ }^{23}$ By conferring this unique right of

17. This Note does not challenge this subsidy to pension plans generally. The size of the subsidy attributable to pension fund taxation has been estimated to be as high as $\$ 56$ billion annually. Goodman \& Harpham, Toward Real Pension Security, Wall St. J., Jan. 22, 1985, at 34, col. 3. It is commonly asserted that the source of the subsidy consists of two principal elements-the ability to invest pretax income (i.e., an employer realizes an immediate deduction, but the employee can defer the payment of tax until withdrawal from the pension fund and therefore invest pretax money in the interim) and the right to earn a return on funds that would otherwise have been paid in current taxes. See A. MunNel., supra note 16, at 36 . The former element, however, is incorrectly identified as a subsidy. The government generally receives identical aggregate taxes whether income is immediately taxed or allowed to compound at pretax rates and then taxed on the compounded value. See Halperin, Avoiding Taxation by Disguising Interest: The "Time Value of Money", 95 YALE L. J. (forthcoming). Alternatively stated, if pension funds were taxable, the advantage of qualified plans would disappear even though the employer's deduction precedes the employee's inclusion. Id. The sole source of the subsidy is the ability to earn interest on untaxed income in a tax-free account. The amount of the subsidy rises exponentially as a function of years invested and the applicable interest rate. Thus, it is due to compounding that the pension subsidy approaches $\$ 56$ billion. For a mathematical expression of the subsidy, see Sunley, Employee Benefits and Transfer Payments, in Comprehensive INCOME TAxAtion 75, 77 n.5 (J. Pechman, ed. 1977). It should also be noted that individuals receiving retirement payments can roll over the funds into an Individual Retirement Account, the financial effect of which is to extend the compounded value of the subsidy. I.R.C. § 402(a)(5)-(7) (West. Supp. 1985).

18. I.R.C. $\S 404(k)$ (West Supp. 1985).

19. I.R.C. $\$ 2210$ (b) (West Supp. 1985). An additional tax benefit, newly granted under the Deficit Reduction Tax Act of 1984, Pub. L. No. 98-369, $\S 541,98$ Stat. 494, 887-90, allows a shareholder to reinvest tax-free the proceeds from the sale of non-publicly-traded stock to an ESOP, provided the funds are reinvested within twelve months and the ESOP holds at least $30 \%$ of all employer securities. I.R.C. $\S 1042$ (a) (West Supp. 1985). This provision may not be a subsidy since it eliminates a bias in the tax code. That is, shareholders can obtain non-recognition treatment of gains through a reorganization. The ESOP rollover provision grants equal tax status to the sale of stock to employees. But the provision gives selling shareholders an incentive to favor bids by an employercontrolled ESOP over other investors, which leads to a distortion in the market for corporate control. See R. Doernberg \& J. Macey, ESOPs and Market Distortions 49-51 (July 23, 1985) (unpublished manuscript) (on file with the author).

20. Small Business Employce Ownership Act of 1980, $\S \S 503-505,15$ U.S.C. $\S \S 632(c)$, 636(a)(15) (1982).

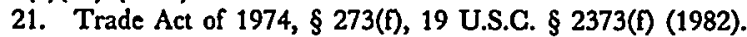

22. I.R.C. $\S 415(c)(6)$ (1982). Under specified conditions, the normal dollar limitation on annual pension allocation to an individual doubles for an ESOP to $\$ 60,000$ (but may not exceed $25 \%$ of employee compensation).

23. ESOPs are the only pension plan permitted to borrow from a party in interest (i.e., the sponsoring corporation) for the purchase of employer stock. ERISA $\S 408(b)(3), 29$ U.S.C. $§ 1108(b)(3)$ (1982). To qualify for the ERISA loan exemption: 
leverage, Congress transforms the ESOP from a retirement account into a "technique of corporate finance," of which the leveraged employee buyout is the leading example.

In a typical leveraged employee buyout, ${ }^{25}$ the corporation borrows funds from a bank ${ }^{26}$ to buy the outstanding shares held by existing shareholders. In turn, the leveraged ESOP trust exchanges a note for a proportion of the stock. The balance of the equity is owned by management and outsiders. $^{27}$

(a) the ESOP must satisfy the statutory definition of ERISA § 407(d)(6), [I.R.C.] § 4975(e)(7)

and IRS regulations;

(b) the loan must be primarily for the benefit of participants;

(c) the interest rate must be reasonable; and

(d) any collateral given by the ESOP to a party in interest must be limited to qualifying employer securities.

J. KAPLAN \& R. Ludwig, supra note 2, at A-14 (footnote omitted).

24. "ERISA made it clear that the ESOP is a technique of corporate finance . . . " Long Statement, supra note 2, at S16636. See also Rev. Rul. 79-122, 1979-1 C.B. 204, 206 (IRS acceptance of ESOPs as corporate finance technique).

The legislative history of the ESOP program frequently refers to the connection between ESOPs and corporate finance. In part, these references serve the interest of congressional sponsors wishing to promote ESOPs as a device suited to the broadest range of corporate activity. See Long Statement, supra note 2, at S16638 ("The Versatile ESOP").

Two more political reasons for the link can be inferred. First, Senator Long introduced ESOPs under the governing authority of ERISA as a matter of legislative practicality. See Granados, supra note 8, at 19-20. The emphasis on corporate finance separates ESOPs as much as possible from the traditional ERISA concern of protecting retirement assets. For the results of this uneasy marriage, see text accompanying notes $35-42$.

Second, the phrase seeks to institutionalize the intellectual lineage of the program owing to Louis Kelso, whose theory of capitalism rests on the proposition that access to credit is the key to unlocking prosperity and encouraging equitable wealth distribution. See generally L. KeLSO \& M. ADLER, THE CAPITAlist MANifesto 224-42 (1958) (exposition of basic theory); L. Kelso \& P. HetTer, TwoFActor THEORY: THE ECONOMics OF REALTTY 45-47 (1967) (same).

As a practical matter, this Note questions the ability of the designated ESOP regulators, the Department of Labor and the Internal Revenue Service, to void abusive ESOP transactions when the language defining permissible structures is as vague and open-ended as "technique of corporate finance." Since innumerable financing transactions crafted by capable lawyers will presumptively meet this test, Congress invites a notoriously skilled bar to exploit ESOP tax subsidies for unintended purposes. Limited staffing at the Department of Labor strongly suggests that these transactions will overwhelm governmental oversight capabilities, particularly given the complexity that financing arrangements are capable of achieving.

25. See supra note 8.

26. The ESOP trust can borrow money directly from lenders, but in practice banks prefer to proceed against the corporation as borrower in the event of default. Qualified lenders are specified as a bank, an insurance company, or "a corporation actively engaged in the business of lending money." I.R.C. § 133(a) (West Supp. 1985). It is reasonable to speculate that investment banks and finance/ leasing firms will devise elaborate syndication agreements designed to pass through the advantage of exempt interest on ESOP loans to high bracket taxpayers.

27. For example, in the 1983 Dan River buyout, employees were allocated approximately $70 \%$ of the outstanding equity, Dan River Inc., Proxy Statement and Notice of Annual Meeting 21 (Apr. 28, 1983), whereas the buyout of American Sterilizer Company utilized a so-called inflatable leveraged ESOP where workers owned no stock immediately subsequent to the buyout, but at the discretion of the new owners (i.e., management) may be offered new equity at a later date. AMERICAN Sterilizer Co., Offer to Purchase 11-12 (Nov. 9, 1984). Equity ownership per se, however, does not insure worker satisfaction. See Hoerr, supra note 3, at 97 (noting dissatisfaction of Dan River employees with structure of the buyout). 


\section{Leveraged ESOPs}

Subsequent to the buyout, the corporation makes annual cash pension contributions to the trust. The trust then immediately returns the funds to the corporation to repay the ESOP note, and the corporation in turn repays to the bank the acquisition debt of the buyout. The result is that employees finance their acquisition of company stock with funds borrowed by the corporation and repaid with firm earnings that have been channelled through the trust as pension contributions. ${ }^{28}$

Funding repayments through the trust thus permits the firm to repay debt with pretax income in the form of a deductible pension contribution. Alternatively stated, the leveraged ESOP structure allows the corporation to borrow money and, upon repayment, deduct principal (up to $25 \%$ of payroll costs) and interest (without limitation). ${ }^{29}$ Whether such a provision constitutes a subsidy is a debatable but usually incorrectly analyzed issue. $^{30}$

Employee buyouts are not limited to the purchase of distressed firms. See supra note 8. The program constitutes a pure financing instrument available to all corporations, including Fortune 500 companies. The critique of this Note is directed at healthy companies capable of using these tax benefits, presumably the firms that Congress most wants workers to own. To the extent congressional and state authorities determine that plant closings and the obligation owed workers in dying industries require special legislation, the umbrella coverage of the leveraged ESOP is an inefficient and improper form of redress.

28. The ESOP shares are initially held in a suspense account. Treas. Reg. $\$ 54.4975-11$ (c) (1977). With each annual repayment from the ESOP to the sponsoring corporation, a proportionate number of shares is released from the suspense account. For two qualifying methods of releasing securities from encumbrance, see Treas. Reg. $\$$ 54.4975-7(b)(8)(i)-(iii) (1977). The released shares are allocated to individual employees based substantially on compensation. From the date of allocation, the shares are further subject to a vesting schedule that can extend as long as fifteen years. I.R.C. $\S 411$ (1982). See also J. KapLAN \& R. LuDwiG, supra note 2, at A-9 (discussing fifteen year vesting period). Departure from the firm prior to vesting results in forfeiture of the unvested shares.

Under the ESOP structure, an employee can receive a cash payment in one of two ways. First, the corporation is required to repurchase vested shares from departing employees when there is no available public market, with the purchase price determined by annual appraisal. I.R.C. $\S 409$ (h) (West. Supp. 1985). Alternatively, the employees will be paid pro rata in the event the company is sold.

29. See I.R.C. $\S 404(a)(9)$ (West. Supp. 1985). All other eligible individual account plans are generally limited to a $15 \%$ corporate deduction, subject to carryovers. I.R.C. $§ ~ 404(a)(3)(A)(1982)$. The ESOP deduction can be applied in addition to deductions taken under other eligible individual account plans. Id.

30. Measurement of a subsidy requires comparision to an alternative normative structure. See supra note 3 . Pension practitioners have long recognized that cash flow effects equivalent to the ESOP principal deduction can be achieved with the combination of debt and a stock bonus plan. See, e.g., Vogel \& Rosen, supra note 11 , at $12,19$.

The difficult, and to some extent unanswerable, question is whether the debt plus stock bonus plan alternative represents the proper incremental comparison for purposes of measuring the repayment provision. A leveraged ESOP is a hybrid of debt (i.e., borrowing against corporate assets) and equity (i.e., sale of stock to employees through a pension trust). The debt or leveraging capacity of the ESOP trust accounts for the corporate finance applications. The equity sale to employees represents the allocation of pension assets.

The debt/equity distinction explains the underlying reason for the debt plus stock bonus plan equivalence. The transaction simply divides in two the implicit instruments of the leveraged ESOP transaction. Moreover, the distinction underscores that employee ownership of company stock equals the value of pension contributions made by the corporation to the trust. Unless one assumes that workers receive a pay increase simply for agreeing to accept a pension contribution in employer stock instead of cash, then employee share ownership represents a portfolio selection. In other words, work- 
Banks and other "qualified lenders" have, as an undeniable subsidy, the right to exclude from income $50 \%$ of the interest earned on an ESOP loan. ${ }^{31}$ This provision alone may reduce financing costs to the borrowing corporation by as much as one-third. ${ }^{32}$

In short, the leveraged ESOP enjoys three layers of tax subsidy, first as a pension plan, second as a qualifying ESOP, and third as a tax-advantaged debt instrument. The critique in this Note focuses on the second and third subsidies ${ }^{33}$ that Congress has bestowed on the acquisition and financing of employer stock by employees. ${ }^{34}$

\section{B. The Political Setting}

Stock ownership confers two general entitlements: one to residual cash flows, the other to a vote in the political governance of the firm. These rights are broadly distinguished by the contrast between ownership and control. Congressional sponsors of the leveraged ESOP program justify the legislation primarily as a means for workers to accumulate a capital estate (i.e., ownership). ${ }^{36}$ Yet under elaborate ERISA fiduciary obligations administered by the Department of Labor, management, as the ESOP trustee, must act solely in the interest of plan participants, in a prudent fashion, and for the exclusive benefit of the employees and their beneficiaries. ${ }^{38}$

ers invest pension contributions in employer stock that would otherwise have been available for investment in the capital market.

Few if any leveraged buyouts are reported to have used the bonus plan alternative. To the extent the bonus plan is not a viable alternative, or is itself an improper subsidy, the ESOP repayment provision likely constitutes a subsidy.

The debt/stock bonus strategy also is no longer a comparable alternative given the subsidies which are unique to the leveraged ESOP structure, especially the subsidy granted to ESOP lenders. See, e.g., Vogel \& Rosen, supra note 11, at 12.

Perhaps most important is whether the leveraged ESOP structure allocates a larger fraction of total employee compensation to pension savings than would otherwise be available under comparable alternatives. This would require a complex examination of, inter alia, tax-deferral alternatives available through the overfunding of defined benefit plans and the use of so-called 401(k) plans, which permit salary income to be exchanged for tax-deferred savings, subject to limitations. I.R.C. $\$ 401(k)$ (West Supp. 1985). Lastly, the leveraged ESOP structure may well force workers to retain more investment in deferred pension income than they find desirable, violating their time preference for money and their level of desired total portfolio risk.

31. I.R.C. $\$ 133$ (West Supp. 1985).

32. See Vogel \& Rosen, supra note 11 , at 12.

33. While this Note does not challenge the general policy of subsidising pension plans, the ESOP structure may permit an excess of funds to be tax-sheltered. See supra note 30.

34. The reason for eliminating subsidies not exclusively related to leverage follows from the analysis of this Note. Subsidizing ownership plans, whether leveraged or unleveraged, does not generate wealth, see text accompanying notes $54-62$, reduces diversification, see text accompanying notes 83-84, and pays corporations to behave as they would otherwise if the incentives operate as presumed by ESOP proponents, see text accompanying notes 73-81.

35. See infra text accompanying notes 43-45.

36. See 44 Fed. Reg. 50367, 50369 (1978) (Department of Labor statement that an ESOP transaction does not void general fiduciary responsibility provisions of ERISA § 404). 
The high standard of fiduciary care mandated by ERISA underscores the interest in ESOPs as a means to transfer control of the workplace to the employees. ${ }^{37}$ In particular, advocates of workplace democracy seek full voting power for employee-held stock, which would include the right to elect the board of directors and thereby set management policy. ${ }^{38}$ More broadly, workplace advocates attack as subversive of the underlying participatory ideal key aspects of the current ESOP regime that operate to entrench management. ${ }^{39}$

The conflict between worker ownership and control represents a political contest of a basic order. ${ }^{40}$ Yet Congress never authorized ESOPs as a vehicle for the fundamental restructuring of political power in the economy. ${ }^{41}$ Furthermore, tying worker control to the flawed economics of the

37. See, e.g., Williams, Buyouts Made with ESOPs are Criticized, Wall St. J., Feb. 21, 1984, at 35, col. 3 (citing Corey Rosen, executive director of the National Center for Employee Ownership: "ESOPs are supposed to be used for the exclusive benefit of employees . . . . If management uses them in any way, they should make a very strong case that the plans are for the interests of workers").

38. See, e.g., Ellerman, Theory of Legal Structure: Worker Cooperatives, 18 J. EcoN. IssuEs 861, 873 (1984) ("The democratic principle of self-government implies that the direct control rights, mainly the voting rights to elect the firm's board of directors, should be assigned to the functional role of being governed, that is, to the people working in the firm." (citation omitted)).

39. See, e.g., Hoerr, supra note 3, at 95 (citing Joseph Blasi, leader of a Harvard University study group on worker ownership: "All too frequently . . companies [with non-employee-voting ESOPs] refuse to use employee ownership to its fullest potential by giving employees real ownership rights and practical and useful participation in the company.").

40. Political advocacy of employee ownership typically takes the form of a contrast between general democratic rights and limited economic rights. See, e.g., Kuttner, supra note 5, at 23 ("The worker may be a full-fledged citizen in the political arena, but as an industrial worker he has no more rights over property than a medieval serf."). The rhetorical appeal to democracy, fundamental property rights and the principles of capitalism highlights the effort to establish employee ownership as a political movement contesting core values. "Worker ownership offers the prospect of extending citizenstyle rights to the workplace by radically democratizing the principles of capitalism rather than by hobbling them." Id. See also Ellerman, supra note 38.

41. If Congress genuinely intended the ESOP program to reorder the structure and practice of capitalism in the United States, it is improbable that the legislative debate would have been characterized by the observation that: "Until now, employee ownership has met with no opposition in Congress." Hoerr, supra note 3 , at 96 . Nor would the program operate through the narrow, technical scope of retirement and tax law. Moreover, program lobbyists admit that the ESOP subsidies in the Deficit Reduction Tax Act of 1984 were obtained in large measure because of the program's "low visibility." Address by Luis Granados, former Legislative Counsel to ESOP Association of America, at the Conference on Employee Ownership, Apr. 26, 1985 (on file with author). Specifically, the 1984 ESOP provisions were described as ones perceived not to "affect that big a sector of the economy and [that] frankly [the public does not] have much input in." Id.

The effectiveness of the ESOP lobbying effort is especially noteworthy given that the Deficit Reduction Tax Act of 1984 was passed to raise revenue. The deal struck by Senator Long involved an agreement to delay for one year a scheduled increase in tax credits offered to a specialized form of ESOP, known commonly as a payroll-based ESOP or PAYSOP. The delay was estimated by the Conference Committee to save $\$ 2.1$ billion over three years, while the new subsidy provisions in the Deficit Reduction Act would cost an estimated $\$ 400$ million. Senator Long was thus able to secure passage of long-sought employee ownership benefits by trading one subsidy for another. Id.

Ironically, the PAYSOP program so lacks in merit that even ESOP advocates deride or minimize its significance. Louis Kelso, for example, calls the program "a government giveaway." Hoerr, supra note 3, at 96. Legislation built on the exchange of suspect subsidies lays small claim to implementing fundamental reform of the economic system. 
leveraged ESOP program risks discrediting profound workplace experiments now underway in the U.S. ${ }^{42}$

\section{The Rationale}

The legislative record indicates that Congress established the leveraged ESOP program to address perceived inequities in the distribution of capital in the American economy. ${ }^{43}$ The principal architect of the program, Senator Russell Long, argues that America has only a "scanty sprinkling of capitalists," concentration, according to Long, fundamentally weakens the economy. New wealth flows to those who are already wealthy while "[m]ost working Americans owe rather than own [and] accumulate debts rather than assets." 45

According to Congress, ${ }^{46}$ the introduction of new technology magnifies the costs to society. Workers steadily lose jobs to machines, with each new round of investment putting the American worker at a greater disadvantage. ${ }^{47}$

To avoid these consequences, program sponsors argue that the government must redirect the flow of capital from current owners. Congress claims that at least eight distinct benefits will stem from the expanded ownership of capital: 1) new wealth and productivity for the economy, 2) a chance for workers to accumulate a capital estate, 3) more jobs, 4) reduced fiscal strain, 5) a principled foreign policy, 6) union-management cooperation, 7) preservation of the marginal enterprise, and 8) expanded consumer purchasing power to "irrigate the economy."48

The principal means by which the ESOP program is claimed to achieve these objectives can be briefly summarized. First, Congress asserts that access to subsidized financing creates wealth for the employees. This argument relies on a model of project finance in which a firm identifies a valuable investment opportunity, such as the construction of a new plant. Corporate borrowing through the ESOP finances the facility. The plant

42. See, e.g., J. Hackman \& G. Oldham, Work Redesign 161-90 (1980) (advocating establishment of self-managing work groups as the basic unit of more effective enterprise production).

43. "A continuing fundamental weakness of our system is that so many Americans own so very little while a relative few Americans own a great deal." Long Statement, supra note 2, at \$16630. In the balance of this Note, congressional purpose is equated with the Long Statement because 1) it is the most recent and complete expression of the intent underlying the ESOP program, 2) the floor statement was cosponsored by 46 Senate colleagues, 3) no additional floor debate was reported in the House or Senate regarding Long's testimony, and 4) the views are consistent with prior legislation.

44. Id.

45. Id. at $\$ 16634$.

46. See supra note 43 .

47. Id. at $\mathrm{S} 16633$.

48. Id. at $\mathrm{S} 16630-35$. 


\section{Leveraged ESOPs}

generates the cash required to repay the ESOP loan and continues on "to generate purchasing power for [the] owners," who are now working Americans, instead of the already wealthy capitalist elite. ${ }^{49}$

Second, Congress states that fairness and equity require the program as the means to distribute future wealth over a broader base. In a capital intensive economy a just return to labor is said to include more than compensation "for work done." benefit from the returns to capital achievable through stock ownership. Proponents of ESOPs advocate that the nation's taxing structure is the appropriate mechanism to redress the inequitable concentration of wealth in the U.S. economy. ${ }^{51}$

Third, Congress accepts as fact that increased ownership improves productivity, citing empirical studies showing higher productivity and improved financial performance for worker-owned versus non-worker-owned firms. The supporting intuition suggests that employees work harder when they are shareholders. ${ }^{.2}$

Because adoption of the leveraged ESOP program implicates the fundamental organization and values of the U.S. economy, these arguments merit close scrutiny.

\section{Analysis of the Congressional Program}

This Section of the Note analyzes the three justifications for leveraged $\mathrm{ESOPs}^{\text {ss }}$ and concludes that each is unpersuasive.

\section{A. Debt Does Not Create Value}

Contrary to the claims of leveraged ESOP proponents, financing employee stock purchases with debt will not increase employee wealth. Senator Russell Long equates access to debt financing with new wealth creation for workers. ${ }^{54}$ This Note maintains that Senator Long's argument,

49. Id. at $\$ 16634$.

50. Id. at $\mathrm{S} 16632$.

51. Id.

52. Id. at $\mathbf{S 1 6 6 3 1 .}$

53. See supra text accompanying notes 48-52.

54. "ESOP financing involves access to credit for the financing of assets which are calculated to generate earnings with which to repay the debt . . . and which can then go on to generate purchasing power for their owners . . . "Id. at S16634. Senator Long explains the logic of ESOP financing with the example of a corporation secking to build a new plant for $\$ 10$ million. With traditional financing, the corporation will borrow the money, backed by adequate collateral, and then "utilize the income generated by the new plant to repay the loan." Id. at S16637. According to Long, the ESOP financing simply adds a third party, the ESOP trust, which uses the borrowed funds "to acquire newly issued employer securities, and the corporation applies the funds to build its new plant." Id. For the fallacy underlying this argument, see infra notes 55-59 and accompanying text. 
which was accepted by Congress and is central to the leveraged ESOP program, is wrong both in theory and in practice.

Take the hypothetical example of a publicly-held company worth $\$ 100$ million. Employees and management join together to take the company private. The assets and future earning power of the firm are used as collateral to raise $\$ 100$ million from the bank. Proceeds of this ESOP loan finance the purchase of the outstanding shares. There is no new plant investment, only a firm recapitalized to the limit of cash flow with debt. Ownership of the company is transferred, but the value of the company remains fixed at $\$ 100$ million.

Two common intuitions explain the fixed valuation. First, value is based on productive capacity, which does not change with a transfer of paper. Second, if debt did increase the value of a company, then all companies would immediately leverage themselves; value-maximizing firms do not leave free money lying around.

These intuitions have been incorporated into a fundamental proposition of finance theory-in a world of perfect capital markets and no taxes, financial structure will not affect firm value. ${ }^{55}$ While the Note will subsequently relax these assumptions, the starting point of public policy analysis must be that debt, by itself, does not create value.

Congress, however, overlooks this fundamental proposition, and instead views the leveraged ESOP structure as a reliable, general mechanism of wealth creation for workers. In terms of the hypothetical $\$ 100$ million buyout, Congress is suggesting that the new company will generate, say, $\$ 10$ million a year for debt repayment, leaving the new owners free and clear with a $\$ 100$ million asset after year ten. ${ }^{.6}$ Understanding the flaw in this example is central to understanding the defect in the leveraged ESOP program.

55. The argument is, first, that investors will not pay more for leverage than they could duplicate themselves, and second, that the increased returns to equity are precisely offset in present value terms by the increased riskiness of the firm's earning potential. In other words, "the market value of any firm is independent of its capital structure . . ." Modigliani \& Miller, The Cost of Capital, Corporation Finance and the Theory of Investment, 48 AM. ECON. REv. 261, 268 (1958) (emphasis omitted); see also R. Brealey \& S. Myers, Principles of Corporate Finance 355-64 (2d ed. 1984) (basic discussion of capital structure and (irm value). Given the ability to deduct interest expense in a world of taxes, the theory has been modified to hold either: 1) that the value of a firm with debt is increased by the present value of the tax shield (i.e., interest expense times the marginal corporate debt rate), id. at $377-81$, or 2) that the inclusion of personal tax considerations may eliminate the value of the tax shield since equity payments are taxed at low capital gains rates whereas investment income can create high ordinary income tax obligations, see Miller, Debt And Taxes, 32 J. Fin. 261, 266-68 (1977). But see R. BREALEY \& S. MYERS, supra, at 387 (Miller's model not completely accepted).

56. The example assumes that the $\$ 10$ million is net of all expenses, including interest. The value of a riskless perpetuity is equal to one year's cash flow divided by the interest rate, or $\$ 10$ million divided by 10 percent, which equals $\$ 100$ million. See, e.g., R. BREALEY \& S. MYERS, supra note 55, at 37 . 


\section{Leveraged ESOPs}

Congress errs by not recognizing that the value of the firm remains unchanged through time. To be more precise, using present value analysis and a ten percent interest rate, the ten-year $\$ 10$ million annuity is worth $\$ 61$ million today, and the $\$ 100$ million capitalized value in year ten is today worth $\$ 39$ million. These add up to a total present value of $\$ 100$ million. ${ }^{37}$ Since the firm was initially purchased in the going-private transaction for $\$ 100$ million, the workers realize no return.

The economic import of this story, lost on Congress, is the need to distinguish between an investment decision (an activity which generates wealth) and a financing decision (a mechanism of payment). ${ }^{68}$ Extending credit to workers, the basis of the leveraged ESOP program, is a financial, not an investment, undertaking. Thus, it is clear that the leveraged ESOP program, as a mechanism of finance, will not generate the wealth promised by Congress. ${ }^{50}$ Its justification must rest on other grounds.

57. Present value, the basis of modern financial theory, in simplest form states that all investments should be evaluated relative to returns which can be obtained in the marketplace. This so-called opportunity cost of capital, here assumed to be 10 percent, can be used to translate future dollars into equivalent present-value dollars. According to the basic formulas, a ten-year annuity of $\$ 10$ million is equivalent to receiving $\$ 61$ million at time zero, while analogously a lump sum of $\$ 100$ million in year ten is today worth $\$ 39$ million, assuming a ten percent discount rate. Id. at $10-13,26-40$. The point of the example can thus be summarized by saying that workers, in order to pay off $\$ 100$ million of current debt, will have to give the creditors all the proceeds of the firm from now to infinity.

58. Financing theory recognizes that an investment decision may interact with the financing decision under some circumstances. For example, a new capital investment may increase the amount a firm can borrow. See id. at 408-12. But such interactions are not involved in selecting the method of financing an acquisition once the purchase price is fixed. In other words, "If capital markets are efficient, then purchase or sale of any security at the prevailing market price is a zero-NPV [net present value] transaction." Id. at 265 (italics omitted).

59. Leveraged ESOP buyouts are sometimes defended based on the comparison to conventional buyouts. See, e.g., Letter from Louis Kelso to the Wall Street Journal (April 15, 1985) (on file with the author). In both instances, runs the argument, debt is assumed, so that the only issue is whether the owners will be the workers or outside investors. ESOP proponents argue that government policy should affirmatively favor worker ownership. Employees are said to be the "natural shareholders" of the firm; capital concentration in the hands of wealthy takeover practitioners is avoided; subsidies ease cash flow repayments for the workers; and the process of broadened capital ownership is set in progress. Id.

At the outset, the argument assumes that tax policy is properly used to influence the form of corporate ownership. Since ESOP subsidies are taken in addition to the tax benefits available to conventional buyouts, chiefly the interest shelter and possible increased depreciation deductions, the ESOP program creates a positive bias towards one method of financing. Government interference with the market for corporate control by biasing takeover bids towards employees does not command wide assent. See R. Doernberg \& J. Macey, supra note 19 , at 45-48.

Moreover, economists now suggest that a principal motivation for the leveraged buyout, conventional or ESOP, is the attendant flexibility to reduce wage costs through layoffs, attrition and a lower wage scale. See Frank, Are Workers Paid Their Marginal Products?, 74 AM. Econ. Rev. 549, 56768 (1984). The ownership stake of the ESOP buyout induces employees to accept less total compensation, in line with their productivity, than they would otherwise agree to in conventional contract renegotiations. The ESOP structure is thus a means to restructure wage claims in a manner palatable to workers, rather than a program of wealth creation or broadened capital ownership. While wage restructuring forced by competitive market conditions is desirable, it is deceptive, wasteful, or both, to pay employees with public tax funds to accept a reduced wage.

The more fundamental point is that buyouts take place in response to market conditions, including perhaps careless conglomerate management, decreasing returns to scale, incorrect allocation of assets, 


\section{B. Future Wealth Distribution-The False Premise}

Congress maintains that the ESOP gives workers access to future wealth in the economy without relying on expropriation or redistributive taxation. $^{60}$ That claim, however, ignores the well-established principle that the purchase price paid for a firm, in an efficient market, reflects the anticipation of future earnings discounted to a current value at an appropriate interest rate. ${ }^{61}$ The buyout forces the market to estimate these variables in arriving at a purchase price. Conceptually, workers, like any buyer, will benefit in a perfect market only to the extent they can generate unanticipated wealth subsequent to the buyout. In no sense can this unanticipated wealth be equated properly with predictable future capital investment by business. ${ }^{62}$ At a basic level, the returns earned by a buyer result from new efficiencies, managerial skill, and innovations, whereas the anticipated return to capital investment is compounded in the present price. The false premise besetting Congress is the notion that wealth is available as an unclaimed commodity. In reality, workers can expect to be compensated on their investments according to the riskiness of the project, no more and no less.

The congressional view underlying the leveraged ESOP program thus

excess wage costs, or a desire to operate as a non-public entity. It might be true in specialized instances that a firm's overriding problem is inadequate worker commitment, in which case it will be expected that firms will efficiently recognize the importance of employee motivation programs. Stock ownership, however, is but one among many tools available to managers and owners to increase worker commitment. See Walton, From Control to Commitment in the Workplace, Harv. Bus. REv., Mar.-Apr. 1985, at 77, 79-81. When other conditions are met, such as stable cash flow and low required investment, then a leveraged employee buyout might result. The point is that the presence of the subsidy should not influence the decision. Nor should Congress mistake the reported large profits on a few well-publicized deals as evidence that money is therefore being stolen from workers' pockets. Leveraged buyouts in themselves promise no salvation. To the extent buyers overpay and fail to realize planned efficiencies, the deals will prove to be losing investments. See, e.g., Deveny \& Ehrlich, Leveraged Buyouts: There's Trouble in Paradise, Bus. Wk., July 22, 1985, at 112, 112-13.

Lastly, arguing that leveraged employee buyouts are good because workers get hold of a company that otherwise would have gone to outside investors, even if true, offers no rebuttal to the general critique of ESOPs presented in this Note. ESOP proponents, moreover, need to explain the troublesome fact that insofar as conventional buyouts achieve improved economic performance, it appears that incentives given to top and line management are sufficient to generate the desired results of the buyout.

60. Long Statement, supra note 2, at S16631-32.

61. See, e.g., R. BreAleY \& S. MYERS, supra note 55, at 272 ("In an efficient market you can trust prices. They impound all available information about the value of each security.").

62. Senator Long argues that cumulative U.S. capital expenditures between 1984 and 2000 of approximately $\$ 2$ to $\$ 5$ trillion represent wealth available for distribution to workers through leveraged ESOP financing. Long Statement, supra note 2, at S16630. To see the fallacy here, consider a single firm. If Senator Long's argument were valid, investors could purchase, say, IBM stock and thereafter see their wealth increase in line with IBM capital spending. Not only would this imply that markets were grossly inefficient (i.e., prices of securities were not reflecting readily available information), but it would also imply that people are failing to take advantage of a near riskless opportunity to amass fantastic wealth. In essence, Senator Long's argument repeats the confusion that future wealth can be distributed through access to credit. 


\section{Leveraged ESOPs}

founders on the initial premise that future wealth can be created through access to subsidized credit. Rather, the wealth creation attributable to an employee buyout can come from only one of three basic channels: undervaluation, tax subsidies, and improvements in firm operations unanticipated in the purchase price. This Note rejects the first two sources of potential wealth because of policy considerations and economic realities. It rejects the third because the program embodies a flawed conception of employee incentives.

\section{Undervaluation}

As a starting point, efficient market theory and supporting empirical evidence suggest that the expectation of undervaluation makes a poor basis for policy ${ }^{63}$ This Note claims further that tax subsidies made available to employees cannot be expected to compete with bids from outside investors attracted by the promise of extraordinary investment returns. And in light of the practical reality that management sets the terms and structure of the deal, potential undervaluations, were they to exist, conflict with established policy.

Public capital markets in general have been shown to do an excellent job of pricing takeovers at their fair market value. ${ }^{64}$ Specific empirical evidence on this point, though somewhat ambiguous, leads to the general conclusion that acquiring firms show no abnormal positive returns subsequent to an acquisition. More certainly, a benefit is captured by the sellers-here the public shareholders tendering to employees and management. ${ }^{65}$ Second and related, in a competitive market for control of companies, workers seeking ownership must bid against private investor groups with substantial capital. As a result, the good buyout candidate-rather than outside financial capital-is today's scarce resource. ${ }^{68}$

63. The basic tenet of efficient capital market theory is that stock prices represent "the best unbiased estimate of the value of a [corporation]." Gilson, A Structural Approach to Corporations: The Case Against Defensive Tactics in Tender Offers, 33 STAN. L. Rev. 819, 858 (1981).

64. See Jensen, Takeovers: Folklore and Science, HARv. Bus. REV., Nov.-Dec. 1984, at 109, 112. Based on sixteen studies that have "painstakingly gathered evidence on the stock price effect of successful takeovers," Jensen concludes that target company shareholders gain $30 \%$ from tenders and $20 \%$ from mergers, while the bidding companies' stock prices increase $4 \%$ from tender offers and realize no return at all from mergers. Id. (prices "adjusted by regression analysis to eliminate the effects of marketwide forces on all corporations"). See also Jensen \& Ruback, The Market For Corporate Control: The Scientific Evidence, J. FIN. EcoN., Apr. 1983, at 5, 5 (reviewing the scientific literature and finding that, in a corporate takeover, target firm shareholders gain, and bidding firm sharcholders do not lose).

65. See Jensen, supra note 64 , at 112 .

66. As one indication of the size of the conventional buyout market, 36 companies went private in 1983 by this route (totaling $\$ 7.1$ billion) as opposed to 16 public-to-private transactions in 1979 (totaling $\$ 636$ million). Much, Leveraging Your Life, Industry WK., July 9, 1984, at 41, 42 (citing report by W.T. Grimm \& Co., merger consultants). One observer estimated the leveraged buyout market will reach $\$ 20$ billion in 1984. Leveraged Buyouts: Switching Corporate Ownership To The 
Companies offering high returns due to an undervaluation that escapes general market scrutiny, and thus presumptively employee scrutiny as well, can therefore be expected to end up in outside investor control through a conventional leveraged buyout or some other form of corporate acquisition. ${ }^{67}$

Private investor groups have the additional advantage over workers of being able to search the market for a particular target of interest. Employees, by contrast, have only the option to buy their own firm, which in practice reflects a buyout decision made by management to which no effective dissent is possible. ${ }^{68}$

An undervalued purchase price might result from management's withholding from the market valuable information about company prospects. But this source of undervaluation is contrary to public policy. And undervaluation due to withheld information offers no gain to society-it leads to a transfer in wealth from selling shareholders to new owners, and requires costly monitoring to ensure that employees are not chosen as equity partners over sophisticated outside investors because the employees can be expected to be more pliant and perhaps vulnerable to accepting a reduced share of new firm earnings. ${ }^{8 \theta}$

Employees, Chemical Wr., Sept. 5, 1984, at 40, 40. With major commercial, investment and specialized banking firms searching the market for potential deals, prices have inevitably risen: "The median-price-earnings ratio paid by investors to acquire companies or business units via an LBO [leveraged buyout] surged to 13.8 times earnings [in 1983], from 8.9 times earnings in 1979. . . Much, supra, at 42 (again citing study by W.T. Grimm). Results would need to be adjusted for movements in the stock market to confirm their significance.

67. Consider as an example the $\$ 40$ million non-employee buyout by management of PhibroSalomon's Natural Resource Division, Phibro-Resources. In the two years preceding the buyout, the division incurred $\$ 158$ million in operating losses and asset writedowns. With $\$ 5$ million in equity, a $\$ 15$ million note from Phibro and a bank credit line, the President of the division, John Lee, joined with a wealthy Saudi investor to take the company private. Within eight months, the company sold its Natural Zinc unit to St. Joe Minerals for $\$ 35$ million, leaving the firm with clear title to a substantial Florida-based fertilizer operation (with access to low-cost sulfur supplies from the Saudi investor), an oil and gas operation and an inactive vanadium processing plant. $\mathrm{Mr}$. Lee is reported to be wellpleased: "This is a textbook LBO. . . . We've made a lot of money and have a lot of borrowing power." Leveraged Buyouts: Switching Corporate Ownership To The Employees, supra note 66, at 43. Clearly markets are not always efficient, and just as clearly, government incentives to share such gains with employees are unlikely to succeed in many circumstances.

68. As long as the buyout plan meets the statutory requirements set out under ERISA and the Code, workers have no power to overturn an employee buyout transaction.

69. See, e.g., Letter from the U.S. Department of Labor to Attorneys for Raymond International, Inc. (Sept. 12, 1983) (Government questions management's taking of a bigger piece of firm's potential appreciation than available to employees), reprinted in LAw \& BuSINESS INC., EMPLOYEE STOCK OWNership Plans Under the 1984 Tax Law 228-35 (1984); Hoert, supra note 3, at 94, 102 (leveraged ESOP buyout "'arguably, a transfer of wealth from the employers to the managers" ) (quoting former Treasury Dept. official). 


\section{Tax Subsidies}

Congress promises that ESOP tax incentives will stimulate new wealth creation, when in fact the program achieves only a tax-based wealth transfer. Specifically, Congress fails to consider the likely consequence of offering tax subsidies in the context of a competitive market for corporate control.

Congress explicitly rejects redistribution through taxation as a policy support for the leveraged ESOP program. ${ }^{70}$ Yet to the extent a firm increases in value due to interest deductions or specific tax benefits, this increase represents a straight transfer from the pockets of the general public to a specific firm, which by the program's own terms must be condemned.

In practice, when conventional financing fails to support a winning bid for a target company, the leveraged ESOP tax subsidies will likely be used to boost the offering price to selling shareholders. ${ }^{71}$ In essence, congressional largesse towards workers will flow through to the selling shareholders. The government has thus shaped a most peculiar transfer program of no discernable benefit to the economy and contrary to the core assumption of the ESOP program that current shareholders are already too wealthy.

Finally, to the extent the firm retains the tax subsidies, the employee buyout structure obtains public funds unavailable to non-ESOP-leveraged businesses. Government-sponsored finance credits thus become an instrument of intra-industry subsidy, violating the principle that the tax code should not discriminate among industry groups or between industry competitors. ${ }^{72}$

\section{Incentive Effects}

The justification for the leveraged ESOP program reduces to an incentive argument. Suggested benefits resulting from employee stock ownership include improved labor-management cooperation and greater productivity from workers, who as equity holders stand to benefit from improved

70. Long Statement, supra note 2, at $\$ 16633$ ("ESOP-type financing techniques are designed to avoid the redistribution of ownership of existing capital for the simple reason that we cannot build a broadly based private property economy on the expropriation of anyone's property.").

71. See Much, supra note 66, at 42 (discussing rising price/earnings ratio for buyout candidates). See also Hyatt, ESOP Changes Could Up The Acquisition Ante, INC., Oct. 1984, at 37, 37 ("There is going to be cutthroat competition between the employee groups and the larger companies. ... Each will try to prove to the owner that its offer is better") (quoting Harvard Professor Joseph Blasi).

72. See, e.g., U.S. Dept. of Treasury, Treasury Report on Tax Simplfication and ReFORM 117 (Nov. 1984) (endorsement by the Treasury Department of a tax system that "will foster neutrality in the selection of organizational form, and in the choice among alternative methods of finance"). 
firm performance. Whether these benefits are in fact realized is in part an empirical question not susceptible to general analysis. Some studies claim to show productivity gains and improved financial performance in workerowned firms, while others detect no benefit. ${ }^{23}$ At this time the evidence must be judged to be inconclusive. ${ }^{74}$

The empirical debate obscures Congress' fundamental error in subsidizing a corporate form of ownership that will be adopted without subsidy if genuinely efficient. The net effect of the tax expenditure will simply be to pay corporations to behave as they would otherwise, but at a substantial cost to the general public.

Moreover, any incentive effects these plans have will be undercut by the practical problems they engender. Specialists in the employee buyout field

73. See, e.g., Rosen \& Klein, Job Creating Performance of Employee-Owned Firms, MonTHLY LAB. Rev., Aug. 1983, at 15, 17 ("Employee-owned companies averaged an annual employment growth rate 2.78 percent higher than that of comparable conventional firms.") McCrackin \& Davis, Employee Stock Ownership Plans: Economic Boon for the Southeast?, EcoN. REv. (Fed. Res. Bank of Atlanta), Oct., 1983, at 20, 21 (in survey of 350 Southeastern ESOPs, few plans seek or realize productivity gains); Livingston \& Henry, The Effect of Employee Stock Ownership Plans On Corporate Profits, 47 J. RISK AND INS. 491, 501-02 (1980) (matching 51 ESOP companies to comparable non-ESOP firms indicates that ESOP companies are less profitable); Marsh \& McAllister, ESOP Tables: A Survey Of Companies With Employee Stock Ownership Plans, 6 J. CoRP. L. 551, 613-16, 619 (1981) (statistical survey of managerial respondents in 128 ESOP companies indicates ESOP companies have markedly higher productivity for the four-year period 1975-79).

74. The National Center for Employee Ownership concluded in 1983 that "there have been few methodologically sound evaluations of [employee stock ownership] plans." Rosen \& Klein, supra note 73 , at 15. More recently, however, the executive director of the organization made the limited claim that "[t]here are now several studies which indicate a strong association between employee ownership and corporate performance." Rosen, Letter to the Editor, Wall St. J., Apr. 30, 1985, at 31, col. 2. In 1986, the General Accounting Office will issue a report on the effects of employee ownership that aims to be more comprehensive than previous studies.

The empirical research taken as a whole reflects the difficulty of isolating the contribution of stock ownership to firm performance. Without an underlying normative model, researchers are generally forced to rely on two methods of analysis: 1) identification of "comparable" non-employee owned firms or 2) an analysis of firms subsequent to implementation of a sizable ESOP. A variety of difficulties arise in basing ESOP research on "employee-owned" versus "comparable" firms, including a bias in selection, an absence of sufficient data, accounting differences, and the failure to prove a causal link between stock ownership and firm performance.

Furthermore, the empirical studies fail to distinguish between improved performance that results from employees' willingness to accept compensation in the form of employer stock as opposed to the ostensible benefits resulting from congressionally authorized access to subsidized credit. Since compensation in the form of stock has no necessary connection to the leveraged ESOP program, the limited research available offers no theoretical justification for continuation of a federal subsidy program.

One consequence of the search to uncover compelling statistics has been the pronounced tendency to overstate findings without noting the severe limitations of the underlying study. This is perhaps best illustrated by the use of a 1977 study commissioned by the Department of Commerce which analyzed pretax profits on sales compared against an industry mean. M. Conte, A. TANnenbaum, D. MCCulloch, EMPLOYEE OWNERSFIP (1981) at 20-27. The study is regularly cited for the supposed finding that employee-owned firms are roughly 1.5 times as profitable as conventionally-owned firms. See, e.g., Long Statement, supra note 2, at S16630; Rosen \& Whyte, supra note 6, at 1 \& n.3; Woodworth, supra note 6 , at 51 \& n.1. What these and other authors neglect to mention about the study is that the profit finding, in addition to its serious methodological problems, has no statistical significance. M. CONTE, A. TANNENBAUM, D. MCGulloch, EMPLOYEE OWNERSHIP, supra, at 23. ("WW]e are not able to claim statistical significance for these figures since the variance in profitability among firms is relatively large and the number of cases is small."). 


\section{Leveraged ESOPs}

describe the initial enthusiasm of workers for the new enterprise structure as a halo effect. ${ }^{76}$ Within a short period of time, tensions inherent in running a successful enterprise can be expected to resurface for reasons relating to lack of control, perceived inequities, and inadequate resources.

Without control of the board, workers in many instances report that the ostensible benefits of ownership appear to be illusory. ${ }^{76}$ Gradual allocation and vesting of shares exacerbate the problem. ${ }^{77}$ The complexity of the new financial structure raises serious problems of fairness, ${ }^{78}$ including the allegation that numerous buyouts entrench management instead of empowering workers. ${ }^{79}$ Related valuation problems arise in pricing the closely-held securities at the time of an employee's retirement or departure from the firm. ${ }^{80}$

The problem of free-riding workers presents serious additional difficulties. Workers who failed to produce at optimal levels prior to the buyout now stand to benefit directly from the exertion of coworkers. Union seniority rules often still control internal governance, making disciplinary actions difficult and costly to enforce. Meanwhile, firm performance, and hence stock value, can decline due to factors beyond a worker's control, an often-overlooked risk of equity ownership. ${ }^{81}$

\section{Systematic Harm of The Leveraged ESOP}

Even admitting the potential incentive benefits of stock ownership, it is nonetheless necessary to consider the injuries to workers and the economy caused by the leveraged ESOP program. Given the breadth of these injuries, the net impact of the leveraged ESOP program will likely be small, or more probably, absolutely harmful to workers.

75. See, e.g., D. Zwerdling, WorkPlace Democracy 78 (1984) (after buyout of furniture plant workers said that the "we saved our jobs" euphoria . . . has begun to sour").

76. Id. at 78-79 (bitterness toward management for lack of control over operations or investments after buyout). Private companies without securities required to be registered with the Securities and Exchange Commission must only pass through voting rights on greater-than-majority issues as defined by law or corporate charter. I.R.C. 409(e) (West Supp. 1985).

77. See Kaplan \& Ludwig, supra note 2, at A3, A9 (reviewing the mechanics of allocation and vesting).

78. Gottschalk, Parson's Acquisition by Employee Stock Plan Raises Some Questions About Who Benefited, Wall St. J., Jan. 29, 1985 at 4, col. 1.

79. See, e.g., Tell, ESOP or MESOP? A Good Idea Is Being Put to Dubious Use, BARRON's, Mar. 18,1985 , at 8,8 .

80. Without a public market, valuation formulas are likely to weight too heavily a firm's book value (because it is known), and undervalue uncertain future investment returns. Financial theory offers little specific assistance beyond setting a broad feasible range of prices. As a result, workers are left to bear the risk of contesting valuations.

81. Regarding the Hyatt-Clark plant, for example, Harvard Professor Joseph Blasi comments, "Worker ownership doesn't magically eliminate the complexities of a poor market, poor management and a poor economy." Leslie, A Modern ESOP's Fable, NewsweEk, Dec. 31, 1984, at 58. 


\section{A. Concentration of Risk}

Employee-owners suffer an immediate reduction in value as a result of losing the benefits of diversification. The loss is significant; ${ }^{\mathbf{2 2}}$ commentators now suggest that the value of diversification may be a principal reason for the prevalent separation of ownership and control in the economy. ${ }^{83}$

Prior to the buyout, employees invest pension assets in a diversified portfolio in the capital markets. After the buyout, workers forfeit their rights to a pension in return for an equity position in the firm. No longer can employees eliminate unique firm-related risks and benefit from productive returns available elsewhere in the economy. Instead, the buyout locks in their capital, eliminating its mobility. The policy runs counter to ordinary notions of prudence, as well as the cornerstone tenet of financial theory that the market will not compensate investors for bearing diversifiable risk. ${ }^{84}$ As a consequence, workers, who have already invested their human capital in the firm, suffer the incremental harm attributable to bearing the unique risk of firm performance. Workers own a single asset far riskier than they would otherwise choose. In the event of bankruptcy, workers lose their jobs and their pension assets. These results alone could be sufficient to justify elimination of the ESOP subsidies.

\section{B. Foregone Investment Opportunities and Reinvestment Shortfall}

In perfect capital markets all investments that create wealth can be financed. ${ }^{85}$ Sometimes, however, investments are subject to capital rationing. Firms are forced to forego valuable investment projects because lending institutions may be unwilling to lend on a project at a competitive rate.

82. In fact, capital asset pricing theory is built upon "the crucial distinction between diversifiable and non-diversifiable risk." R. BREALEY \& S. MYERS, supra note 55, at 784.

83.

The critical financial characteristic of private corporations is that the absence of a public market prevents their owners from achieving optimally diversified portfolios by selling off a portion of the ownership of the private company. As a result, the company may well be worth more to a publicly held acquiring company, whose shareholders can optimally diversify, than to the private owners of the company.

Gilson, Value Creation by Business Lawyers: Legal Skills and Asset Pricing, 94 YALE L.J. 239, 283 n.111 (1985). The benefits of diversification would also apply to investors in private buyouts who hold a sufficiently large and diverse portfolio. For a discussion of the well-documented benefits of diversification under modern financial theory, see, e.g., R. BREALEY \& S. MYERS, supra note 55, at 123-26.

84. See id. at 140 ("Since investors can diversify away unique risk, they will not demand a higher return from stocks that have above-average unique risk. . .. [T] [Te capital asset pricing model states that the expected risk premium from any investment should vary in direct proportion to its market risk.").

85. See id. at 19 (perfectly competitive capital markets imply: no barrier to financing wealthgenerating projects, zero transaction costs, no distorting taxes, and costless, widely disseminated information). 


\section{Leveraged ESOPs}

The leveraged buyout creates an extreme case of capital rationing enforced by lenders through restrictive covenants limiting firm operations as a condition of the loan. In pledging debt capacity to the lender, the firm loses investment opportunities it might otherwise have undertaken. While the cost of foregone projects is difficult to quantify, the value of the firm is undeniably reduced by the capital constraint. ${ }^{88}$

A distinct, but related problem is the reinvestment shortfall facing the employee-owned firm. In broadest terms, a firm's ability to reinvest for future earnings depends crucially on its net cash flow. In the early years of the buyout, free cash flow is negligible since the funds ordinarily available for investment must be paid over to the acquisition lender instead of being reinvested by the firm. In addition, unlike the conventional buyout, the ESOP-financed takeover faces a major additional drain on its investment resources from the obligation to repurchase stock from departing employees. ${ }^{87}$

The employee-owned firm thus confronts two barriers to investment cash generation: the debt repayment obligation and the repurchase liability. Moreover, the firm must typically reduce capital investment spending for many years, thereby sacrificing a critical ingredient of higher productivity. ${ }^{\mathbf{8 8}}$

86. See id. at 103-07 (shareholder wealth reduced if both firm and shareholder are barred from well-functioning capital markets).

87. See Schuchert, ESOP Leveraged Buyouts, in Employee Stock Ownership Plans under the 1984 Tax Law 179, 199-201 (R. Ludwig \& R. Reichler eds. 1984). According to a recent analysis by two prominent theorists, the limited market for closely-held stock generates an additional incentive to systematically underinvest. Fama \& Jensen, Organizational Forms \& Investment Decisions, $14 \mathrm{~J}$. Fin. ECON. 101, 107 (1985) ("The difficulties in designing valuation processes to substitute for the capital market ... means that partnerships and closed corporations will not generally follow the value maximizing decision rule. They will tend to underinvest in assets with long-term payoffs whose current value are not easily established."). The underinvestment bias is reinforced by the limited diversification, which leads closed corporation equity holders "to undervalue claims on future cash flows" relative to wealth-maximizing decision rules followed by open (i.e., public) corporations. Id. at 119.

88. For the underinvestment bias in closely-held corporations, augmented by limited diversification, see supra note 87.

Moreover, many leveraged buyouts, whether conventional or ESOP-based, are not prone, absent excellent management, to produce productivity gains beyond those realized in restructuring an inefficient organization. Lenders demand and buyers seek out mature businesses characterized by a stable cash flow stream. These stable flows are typically generated by established, low growth firms where the prospect of recurring gains from improved labor productivity is slim. See Kaufman, Lang, Ley and Messineo, Leveraged Buy-Outs and Other Asset-Oriented Transactions, in Practicing Law Institute, Corporate Law and Practice Course Handbook No. 419, acguisition and Merger Tactics and Technology 1983, at 411, 414.

Underinvestment in the employee buyout firm compounds the problem because, as Senator Long ironically recognizes, "[p]roductivity is, in part, dependent upon individual effort. However, and this is particularly true of our crucial infrastructure, to a great extent productivity is dependent upon technological advances...." Long Statement, supra note 2, at S16631 (emphasis added). 


\section{The Final Period Problem}

Workers nearing retirement in the employee-owned firm have a strong interest in protecting the value of their shares. They will understandably vote and lobby against investments of extended maturity. ${ }^{89}$ The buyout accentuates the much-criticized tendency of American business to focus on short-term profits, both because of the enormous debt load, and because of the interest of workers in protecting the value of their investment.

Finance theory identifies this problem as one of incompatible time horizons. ${ }^{90}$ While the value of the firm would benefit from a long term investment horizon, retiring employees maximize their individual return by avoiding projects with distant payoffs. The horizon problem is a serious, predictable, and real cost of the buyout. ${ }^{91}$

\section{The MODEL FOR REFORM}

As the first step to reform, Congress should eliminate all ESOP subsidies which supplement the tax benefit already granted to pension investments generally. ${ }^{92}$ Terminating these subsidies would send the proper signal that the government recognizes that subsidy credits in the buyout market do not benefit workers, the companies they own, or the economy at large. ${ }^{93}$

89. See Jensen \& Meckling, Rights and Production Functions: An Application to LaborManaged Firms and Codetermination, 52 J. Bus., 469, 483 (1979) ("WW]orkers [in a labor-managed firm] have strong incentives to behave in ways which maximize the near-term net cash flows of the firm."). Among the strategies available to workers are increased salaries in place of maintenance, cash payout of borrowings where the repayment obligation falls to future employees, selected investment in projects with high near-term cash flows, and sharp increases in pension benefits, again with the costs deferred to the future. $I d$. at $483-84$. The tendency to underinvest is compounded by stock repurchase formulas weighted toward book value. See supra note 80 .

90. Capital asset pricing theory depends on the assumption that investors have a common time horizon. Gilson, supra note 83 , at 252 . When this condition fails, as in the employee-owned firm, "strategic, opportunistic behavior" can be expected as the parties seek to "maximize value in the period relevant to [them], even at the expense of a decrease in value in the period relevant to the other party. This conflict reduces the value of the [enterprise]." Id. at 265.

91. As an example, consider the case of Hyatt-Clark, a $100 \%$ employee-owned operation divested in 1981 by General Motors. In 1984, the company reported a six month profit of $\$ 2.2$ million, entitling the workers under an old contract to $\$ 600,000$ in profit-sharing compensation. See, Leslie, supra note 81 , at 58 .

In response to management's decision to postpone the profit-sharing in anticipation of a $\$ 14$ million capital expenditure program, workers organized a slowdown that cost the company an estimated $\$ 4$ million. To avert a strike, which would have meant the loss of its biggest customer, General Motors, a new contract was signed. The chairman of the company is reported as saying that he did not know where the company would get the money to pay for the new contract. Id.

92. See supra text accompanying note 16-33.

93. The Treasury Department, in response to President Reagan's 1984 call for comprehensive tax reform, proposed the elimination of the 1984 ESOP subsidies, as well as the elimination of most other specialized ESOP benefits. See U.S. DEPT. OF TREasury, TREASURY RePORT ON TAX SimplificaTION AND REFORM 324-27 (Dec. 3, 1984). The tax reform package submitted by the President to Congress, however, rejects this approach and instead proposes to remove ESOPs from the statutory control of ERISA and significantly expand employee rights to vote and sell their shares. See THE 
If firms believe that workers who are shareholders work harder, Congress should be confident that this aspect of the program will be perpetuated by competitive markets without the lure of subsidized indebtedness. Specifically, firms are free to compensate workers with relatively more stock and less wages. This approach would mimic management executives' mixed compensation plans of salary and performance-related bonuses.

Traditionally, organized labor has opposed profit-sharing plans that replace current compensation ${ }^{94}$ because they want to protect workers from the risk of declining performance. Even if this union opposition is shortsighted, a subsidized program of stock ownership is not the proper vehicle to shift worker compensation toward incentive pay. The current leveraged ESOP program tries to hide the change in risk structure with incomplete and incorrect arguments about wealth creation and equity ownership.

President's Tax Proposals to the Congress for Fairness, Growth, and Simplicity, $314-$ 19 (1985). Virtually all the ESOP tax subsidies are retained, eliminating only the assumption of estate tax liability by the ESOP. In addition, firms would be obligated to pass through to workers any savings realized by deducting ESOP dividends. The principal guiding the proposed changes is that ESOPs should promote direct employee ownership, rather than serve as a retirement vehicle.

The proposal exposes the fundamental weakness of the ESOP program. The basic defect remains that no persuasive justification is given for continued subsidization of stock ownership. In fact, the value of the subsidy is potentially increased due to a related proposal change limiting the deduction for stock bonus plans to $15 \%$ of payroll compensation. See id. at 351-54.

Ironically, the move toward freely alienable ESOP stock, a correct economic proposition, further undermines the rationale for subsidizing leveraged stock ownership. Workers are encouraged under the President's proposal to behave as investors, holding stock because they view it as a good investment, but one to be sold presumably when the expected return falls relative to investments of comparable risk. Since leveraging does not affect firm value, except possibly due to the wealth transfer from the general public in the form of an interest tax shield, no reason exists for tying ESOP subsidies to debt financing.

The investment decision highlighted by the Reagan proposal correctly recognizes that ESOPs represent an allocation of worker wealth to employer stock. Yet there is no reason to believe that employer stock should be systematically undervalued relative to alternative investments. In fact, it is a logically impossible condition to apply to firms in general (i.e., to the extent all firms are "undervalued," no relative advantage accrues to investing in employer stock, and likewise all investors taken individually cannot all do better than the average).

From an investment perspective, the leveraging allows workers to borrow against future compensation to purchase employer stock at the current price, instead of at an annually fluctuating rate. But such an investment decision cannot credibly be tied to a subsidy that systematically biases workers into believing that today's price is uniquely undervalued relative to future investment opportunities in either the firm or comparable investment alternatives. Nor does the Administration proposal address the problem of valuing private enterprises, where efficient pricing is unlikely to result from appraisals, or the fact that in public firms workers already have the resources at hand in the form of accumulated pension income to make sizable investment purchases of employer stock were it so desired.

At most, then, the President's proposal recognizes the inconsistency of ERISA and the ostensible aims of the ESOP program, see supra text accompanying notes 35-42, and narrows the sole rationale for the program to the incentive argument, rather than the access to credit theories embedded in the legislative record. Unfortunately, the Administration has missed an ideal opportunity for tax reform by mistaking correct principles of economic freedom for the invalid claims of subsidized employee stock ownership.

94. See, e.g., Woodworth, supra note 6, at 47. 
Congress, by focusing on compensation, would return the debate about stock ownership to a proper grounding in financial reality. ${ }^{95}$

More speculatively, Congress should permit workers greater control over the pension assets that they have already earned. Private pension assets alone total approximately $\$ 900$ billion, ranking these funds as one of the largest sources of discretionary investment capital in the economy. ${ }^{96}$ To the extent workers want more control, Congress should consider letting workers invest these accumulated funds in company stock. The loss of diversification benefits would be obvious, not hidden as they are under the current regime. And, arguably, this risk-reward tradeoff belongs not to society but to the workers who own these assets. ${ }^{97}$

95. Martin Weitzman in a recent book argues that compensation pegged to firm performance, if adopted by a significant proportion of the economy, has the potential to simultancously combat stagnation and inflation. M. Wertzman, The Share Economy: Conquering STAGflation 72-95 (1984). The underlying rationale is that a fluctuating wage frees firms from a concern with overhiring since their wage bill will fall in tandem with declining performance. The result is a permanent excess demand for labor. Id. at 84-88. Achieving this condition underlies the central macroeconomic claim that a "share economy" will tend to be less subject to cyclical downturns and cost-push inflation. Id at 106-07, 111-18.

To achieve the "public good" of a share economy, Professor Weitzman argues that tax subsidies be given to the "share" portion of employee earned income. Id. at 129-31. Whatever the eventual merit of the Weitzman proposal (see Matthews, Book Review, 23 J. Econ. LrTERATURE 658 (1985) (critiquing Weitzman's book)), the point can be made that the share economy does not provide an unintended basis for continuation of the leveraged ESOP pension subsidy.

Insofar as the ESOP program reflects the theorizing of Louis Kelso, the underlying assumptions of Kelso and Weitzman stand in opposition. Specifically, Kelso claims that capital ownership must be subsidized for workers because labor earns "less that $10 \%$ of U.S. personal income." Kelso Letter, supra note 59. Professor Weitzman almost precisely inverts these figures, estimating that the return to labor constitutes $80 \%$ of annual national income, with the balance flowing to unearned income in the form of capital gains, and tax-free municipal interest income, among other sources. See WEITZMAN, supra, at 129; S. Speiser, A Piece of THE ACTION 112 (1977) (quoting Professor Paul Samuelson that, contrary to Kelso's claims, labor earns approximately $75 \%$ of gross national product). Thus, to accept Weitzman's theory, even as a speculative economic proposition, is to reject the fundamental authority for the leveraged access to capital underpinning the Congressional ESOP program.

Weitzman's theory also establishes the justification for the subsidy as promoting a shift in the macroeconomic behavior of the economy, not as the result of incentives for increased individual efforts. WEITZMAN, supra, at 142-46. The ESOP program, in contrast, rests on propositions about debt financing that this Note argues are unsupported either in theory or practice.

Finally, Professor Weitzman himself sees no connection between ESOP subsidies and improved macroeconomic performance, especially in the area of job creation, which is a prime aspect of his share economy proposal. The ESOP program in his view could play a valuable role in easing the transition for hard hit distressed industries. But as a general policy initiative, he rejects the claim that ESOP subsidies create wealth or broaden capital ownership. Telephone interview with Martin Weitzman (July 23, 1985).

96. See, e.g., Goodman \& Harpham, Toward Real Pension Security, Wall St. J., Jan. 22, 1985, at 34 , col. 3 .

97. The loss of diversification could impose so great a cost that it forces a policy conclusion that restraints need to be imposed on permissible investment strategies, thereby affirming the general value of ERISA-based regulation. The aggregate risk of the investment may be more than most workers prefer. Moreover, the government may be forced to intervene in any event should a pension investment failure leave hundreds of thousands of employees without any retirement income. 
Leveraged ESOPs

\section{CoNCLUSION}

The federal leveraged ESOP program stands condemned on numerous grounds. Principally, the economics underlying the program are without merit. Congress mistakenly assumes that granting workers access to subsidized credit can create wealth. In addition, the program forces workers to concentrate all their holdings in the firm. The loss of diversification imposes costs borne willingly by no other group of investors in our economy. Finally, to the extent that equity ownership improves productivity, market incentives will efficiently lead firms to compensate employees with stock. By eliminating tax benefits for leveraged ESOPs, Congress can at once save substantial public funds and acknowledge that subsidized ownership of stock will not lead to worker capitalism or a more productive economy. 